\title{
Otimização do sistema de produção de clones por transferência nuclear com a utilização de oócitos vitrificados e diferentes tipos celulares como doadores de núcleo*
}

FABIANA FORELL

\author{
José Luiz Rodrigues (Orientador - UFRGS)
}

Banca: Adriana Bos Mikich (UFRGS), Alexandre Tavares Duarte de Oliveira (FFCMPA), Marcelo Bertolini (UDESC), Rui Fernando Felix Lopes (UFRGS)

A técnica de transferência nuclear é uma ferramenta que possibilita a produção de embriões clones que podem ser utilizados tanto na clonagem reprodutiva, proporcionando o nascimento de produtos, como modelo para o estudo de diversos mecanismos fisiológicos durante o desenvolvimento embrionário. Este trabalho teve como objetivos a otimização da técnica de clonagem no Laboratório de Embriologia e Biotécnicas de Reprodução (FAVET, UFRGS), avaliar a taxa de sucesso da clonagem interespécie, e testar a eficiência da utilização de oócitos vitrificados como citoplasmas receptores para a reconstrução dos embriões clones, sendo realizado em três etapas. A primeira teve por objetivo o estabelecimento da técnica de clonagem, bem como sua otimização nas nossas condições, dando condições para que os experimentos subseqüentes pudessem ser realizados. Para isto, foram realizados experimentos in vitro comparando diferentes meios de manipulação, sistemas de ativação química, meios de cultivo e fontes protéicas no cultivo dos embriões, e células oriundas de diferentes origens e animais como doadores de núcleo. Os resultados obtidos in vitro alcançaram taxas de 64,7\% de clivagem e de $19,5 \%$ de blastocistos. Um grupo de embriões foi transferido para receptoras ( $\mathrm{n}=24)$, e foram observadas 54,2\% de prenhezes aos 35 dias, 8,3\% de prenhezes aos 260 dias e 4,2\% de nascimentos. A segunda parte dos experimentos teve por objetivo a produção de clones interespécies utilizando o citoplasma bovino como receptor para células ovinas, caprinas e suínas. As taxas de clivagem nos grupos NTSCi ovino $(60,3 \%)$, caprino $(68,4 \%)$ e suína $(57,1 \%)$ não diferiram dos grupos controles NTSC bovino. A taxa de blastocisto observada nos embriões NTSCi ovinos (10,3\%) foram semelhantes às taxas observadas no grupo NTSC bovino $(12,7 \%)$. No grupo NTSCi caprino, 5,3\% dos embriões chegaram ao estádio de blastocisto, enquanto que no grupo NTSCi suíno não houve desenvolvimento até o estádio de blastocisto. Na terceira parte do trabalho, experimentos visando a utilização de oócitos vitrificados imaturos, com citoplasma receptor, foram realizados. Foram submetidos à maturação 764 complexos cumuli-oócitos vitrificados, e 73\% destes foram recuperados após o desnudamento, e 46,8\% apresentavam corpúsculo polar, taxas significativamente inferiores às observadas nos oócitos não-vitrificados $(91,4 \%$ e $65,8 \%$, respectivamente). As taxas de sobrevivência após a micromanipulação $(77,8 \%)$, taxa de fusão $(82,1 \%)$ e de sobrevivência após a ativação (79,9\%) do grupo vitrificado, não apresentaram diferença significativa com o grupo controle não-vitrificado. As taxas de blastocistos também não apresentaram diferença entre os grupos vitrificado e não-vitrificado (16,7\% e 23,4\%), respectivamente. Em resumo, os resultados deste trabalho demonstraram que oócitos bovinos frescos ou vitrificados, nas nossas condições estabelecidas, foram capazes de suportar o desenvolvimento de embriões clones bovinos até o estádio de blastocisto ou a termo, e proporcionaram citoplasmas compatíveis para o desenvolvimento de embriões clones interespécie até o estádio de blastócito.

Descritores: clonagem, transferência nuclear, vitrificação, interespécie, bovinos.

Apresentada: 27 fevereiro 2008

*Tese de Doutorado n. 92 (Especialidade: Reprodução Animal/Biotécnicas de Reprodução). 137f. Programa de Pós-graduação em Ciências Veterinárias [www.ufrgs.br/ppgcv], Faculdade de Veterinária, Universidade Federal do Rio Grande do Sul (UFRGS), Porto Alegre/RS. CORRESPONDÊNCIA: F. Forell [fforell@yahoo.com.br]. 


\title{
Optimization of cloning by nuclear transfer procedures using vitrified oocytes and distinct cells as nuclear donor**
}

\author{
FABIANA FORELL
}

José Luiz Rodrigues (Adviser - UFRGS)

Committee: Adriana Bos Mikich (UFRGS), Alexandre Tavares Duarte de Oliveira (FFCMPA), Marcelo Bertolini (UDESC), Rui Fernando Felix Lopes (UFRGS)

Somatic cell nuclear transfer (NTCS) procedures is a valuable tool for the production of clone embryos for use in reproductive cloning, by providing the birth of live animals, and for use as a research model, allowing the study of physiologic mechanisms during the embryonic development. This work aimed to optimize cloning procedures at the Embryology and Reproductive Technology Laboratory (FAVET, UFRGS), to evaluate the success rate of interspecies cloning, and to test the effectiveness of vitrified oocytes as recipient cytoplasm for embryo reconstruction, being carried out in three stages. The first stage was focused on the establishment of the cloning technique and the optimization of procedures and conditions in the lab so that the subsequent experiments could be accomplished. Thus, in vitro experiments were performed to compare different manipulation media, chemical activation systems, manipulating media, source of protein supplementation to the embryo culture media, and distinct cell types and genotypes. The mean cleavage and blastocyst rates obtained after conditions were optimized were $64.7 \%$ and $19.5 \%$, respectively. Pregnancy rates on Days 35 and 260 of gestation and calving rate at term following the transfer of a group of embryos to synchronous recipient cows $(n=24)$ were $54.2 \%, 8.3 \%$ and $4.2 \%$, respectively. The second stage of the study evaluated the success rate of the production of interspecies clones (NTSCi) using the bovine oocyte as recipient cytoplasm for transferred nuclei from ovine, caprine or porcine cells. Cleavage rates using ovine $(60.3 \%)$, caprine (68.4\%) and porcine (57.1\%) nuclei did not differ from controls (bovine nuclei). Blastocyst rates observed for NTSCi embryos using ovine nuclei $(10.3 \%)$ were similar to those observed in the bovine NTSC group (12.7\%). The NTSCi-caprine group reached a 5.3\% blastocyst rate, whereas no development to the blastocyst stage was observed when using porcine cells as nucleus donor. In the third stage of this work, experiments evaluated the efficiency of vitrified bovine oocytes as recipient cytoplasms for cloning by TNCS. Following vitrification and warming, 764 cumulus-oocyte complexes were in vitro-matured. A total of $73 \%$ was recovered after cumulus removal, with $46.8 \%$ presenting visible polar bodies, which were significantly lower than rates observed in non-vitrified oocytes $(91.4 \%$ and $65.8 \%$, respectively). However, survival rates following micromanipulation $(77.8 \%)$, fusion rates $(82.1 \%)$ and survival after activation $(79.9 \%)$ of oocytes were not different from the control group (non-vitrified oocytes). In addition, blastocyst rates did not differ between vitrified and non-vitrified groups ( $16.7 \%$ and $23.4 \%$, respectively). In summary, results from this study demonstrated that fresh or vitrified bovine oocytes, under our optimized conditions, were able to support development of bovine clone embryos to the blastocyst stage or to term, and provided a compatible cytoplasm for the development of interspecies clone embryos to the blastocyst stage.

Key words: cloning, nuclear transfer, vitrification, interspecies, bovine.

\footnotetext{
**Doctoral Dissertation \#92 (Field: Animal Reproduction/Biotechnology of Reproduction). 137p. Graduate Program in Veterinary Sciences [www.ufrgs.br/ppgcv], Faculdade de Veterinária, Universidade Federal do Rio Grande do Sul (UFRGS), Porto Alegre/Brazil. CORRESPONDENCE: F. Forell [fforell@yahoo.com.br].
} 